\title{
Identity of Highly Educated Returnees in Serbia
}

DOI: https://doi.org/10.11567/met.35.2.4

UDK: 314.151.3-057.85(497.11)

Izvorni znanstveni rad

Primljeno: 07.04.2018.

Prihvaćeno: 01.10.2019.

\section{Milica Vesković Anđelković}

Department of Sociology, Faculty of Philosophy, University of Belgrade, Belgrade milica.ves@gmail.com

\section{Mirjana Bobić}

Department of Sociology, Faculty of Philosophy, University of Belgrade, Belgrade mirjana.bobic@gmail.com

\section{SUMMARY}

The paper examines the data collected through interviews with 50 highly educated returnees from Serbia, carried out in 2017. The main objective was to understand the personal and group identities of Serbian citizens with an experience of migration. The authors applied two conceptual paradigms: first, a primordial one, presupposing that migrants fully preserve their national identity despite being exposed to different cultures, customs, and values at the destination. The second is a social constructionist one, which is further delineated into two main lines of thought: the one assumes that migrants maintain national identity as a "hard core", yet in a continuous process of remaking/recreation as a result of embracing transnational ties. The other which presupposes that migrants build hybrid identities in a permanent flux because they are not firmly grounded in any specific culture. The interpretation of results indicated that a vast majority of returnees have devised hybrid identities. This means that destination society and culture have significantly effected their identity but national roots have still been preserved. The latter is mirrored in their strong sense of belonging to the nation. This may be interpreted as a consequence of two main circumstances. It is hard to expect that national identity can remain unmodified when migrants enrol in educational institutions and bond with scholars all over the world. Besides, the very fact of having maintained national identity made them willing to return and contribute to homeland development, despite Serbia's lagging behind the social and economic developments of countries they had been living in. The results also revealed that the interviewees did not perceive any major difference in national belonging between themselves and non-migrants in Serbia. On the contrary, they did perceive this difference when it came to the diaspora.

KEY WORDS: identity, diaspora, transnationalism, highly educated returnees, Serbia 


\section{INTRODUCTION}

The interest in identity can be traced back to ancient philosophers, primarily Plato and Aristotle. It can be said that, aside from other topics and problems, the whole history of philosophy has been permeated with this issue. Nonetheless, while the very meaning and essence of this concept have been constantly evolving (Đurić, 2009), its contemporary understanding stems from Western individualism.

The rejection of both the traditional and Christian worldviews in the 18th century was followed by a search for a new, secular identity. The tension between the human being and society advanced in the 19th century. Both the individuals and groups expressed a strong tendency to differentiate themselves from others, thus striving for uniqueness. This individualism came further to the fore during postmodernism and has become ever more empowered by the recent globalisation (Golubović, 1999: 7).

Other than boosting the global economy, the last wave of globalisation has enabled a free flow of people and ideas owing to the widespread and open use of information technology by the vast majority of people. The plurality of choices and chances provides possibilities for building various identities and creating authenticity, which has come to the fore ever since the rejection of the ideals of traditional society. However, the abundance of open prospects, unknown to traditional societies and their value systems, has brought about feelings of alienation and insecurity. Bolstering ethnic and national identity as firm footholds has become one of the not so infrequent reactions (Takeyuki, 2001). These identities have multiplied in today's world despite many attempts to achieve cultural unification (Šolte, 2009).

The development of and access to contemporary means of communication have also influenced the identity formation of today's migrants. Immigrant populations are expected to accept the customs and culture of a destination and gradually cut ties with the country of origin, thus becoming assimilated into a new community. However, owing to the Internet and various programs that enable cheap interaction between migrants and their relatives and friends staying behind, a change of residence does not necessarily mean cutting ties with places and communities of belonging. Exchange with the homeland now occurs in transnational spaces, thus inducing the process of recreation of personal, as well as group, national identity (Glick Schiller, Basch and Blanc-Szanton, 1992: 1). Besides, transnational spaces also facilitate the establishment of firm and stable networks at receiving 
societies, thus shaping migrants' lives even though their new and final destination might be their very country of origin, as is the case with returnees (Takeyuki, 2001).

The main objective of this paper is to understand the feelings related to identity or the sense of belonging among returnees who either completed some level of education or worked abroad after graduating from universities in Serbia. The interpretation of results is based on the data collected through qualitative fieldwork with the main purpose of exploring possibilities for mobilising returnees into homeland development.

It is important to stress that our fieldwork was not focused on identity. The study of its nature, characteristics, and significance for the respondents was carried out to test the hypothesis regarding the importance of national identity as an incentive to invest resources accumulated abroad into the homeland. Besides, the creation of the instrument for data collection strongly relied on the main theoretical underpinnings, which made it possible to analyse the statements concerning personal identity. This theoretical framework will be elaborated in the next chapter.

Having in mind the macro-structural theories which accentuate the context as an important element in understanding the process of migration and identity (Cassarino, 2004), the third chapter provides a short review of the specific socio-political context in Serbia following the collapse of state socialism and the onset of long-term post-socialist transformation, since these were the times when our respondents were leaving and later returning to the country. The fourth chapter lays down the research methodology and is followed by a discussion of the main findings. Finally, the last chapter presents some concluding remarks.

\section{CONCEPTUALISATION}

Beginning at the end of the 20th century, the new wave of globalisation has been characterised by a technical and information revolution, concomitant compression of time and space, the diffusion of the market economy, global corporations, etc. All of these factors have strongly impacted the issues of national identity. While the consequences of these trends are manifold, this paper will focus on the most important ones, such as the status of migrants at a destination, which influences the shaping of their identity and the persistence of a particular national gradient within it. 
For authors whom David Held names hyperglobalists (Held and McGrew, 1999), ${ }^{1}$ globalisation represents the implosion of national identities and specificities in a political as well as cultural and economic sense. However, the truth is that not only has globalisation failed to annihilate nation and national identity but it has also caused a burgeoning of local sentiments of belonging. It has also brought about a rise of collective identities beyond the national level, i.e. nationalist sentiments of people who do not possess their own states. The examples are numerous: Quebeck, Norway, Slovakia, Bangladesh, Chechnya, etc. (Pavković and Radan, 2008). Some authors claim that today's globalisation denotes an era of revival of nationalisms, which is reflected in resistance to established nation-states (Bisley, 2007).

The strengthening of national identity is also a result of a personal identity crisis as a consequence of varying options and values provided by information technology. Earlier, in traditional societies, people defined themselves by the roles they played within society, so their identity was vastly socially constructed. In modern times, each individual creates their own identity, choosing among a plurality of options and evaluating them in accordance to what Charles Taylor labelled as the ideal of authenticity (Golubović, 2009: 11). Besides, one does not need spatial proximity to develop a group or collective identity. Much more significance is gained through "...networks of interpersonal ties that provide sociability, support, information, a sense of belonging" (Welman, 2001: 228). Thus, the evolution of information technology brings about the privatisation of life (Bauman, 1994), marking a node of various overlapping communities based on virtual networks. Therefore, contemporary information and communication technologies lay a myriad of possibilities before a person, all of which are important for identity formation and authenticity under particular social settings.

Identity building and social recognition are also related to anxiety, which has become one of the features of personality in modern times (Kelner, 2004). This feeling of unease stems from the surplus of options, from the

Having in mind the different approaches to globalisation, Held and McGrew (1999) divided authors into three groups:

1. Hyperglobalists - those who see globalisation as a completely new era, which is characterised by global capitalism, global management, and global civil society. The basis for this understanding is that the decision centre is beyond the nation-state;

2. Sceptics - those who think that economic interdependency is anything but new. In that sense, it is more plausible to discuss globalization more as an integration of national states and less as an entirely integrated world economy; and

3. Transformationalists - those who believe globalisation is a long-term historical process with inherent contradictions, which depends on a series of factors. 
need for acknowledgement and appreciation of identity by others, and, finally, from the multitude of "we" identities, all of which pose a risk of losing oneself in a multitude of sometimes mutually conflicting roles. The result is a crisis of identity and a need for security.

It is exactly at this point when one starts to strive for a firm foothold, which may be found in national and ethnic identity. Common roots provide sentiments of stability, belonging and permanence both in individual life and in relationships with others (Golubović, 1999; Žižek, 2001). This need for a firm ground in the perception of self and others, which is evident in the sense of belonging to a group based on ethnic origin, myths, and collective memories (Smith, 2009), demonstrates the persistence of national identity and national communities despite all other influences present in the contemporary world.

It is important to underline that these communities have always been imagined, meaning that people are aware that they cannot get to know other members. Rather, "in the minds of each lives the image of their communion" (Anderson, 1999: 49). As Anderson further claims, this communion could never be placed in the boundaries of one state, although it could be imagined in this way (Anderson, 1999). The latter has often been the case when attempting to understand international relations (Glick Schiller and Fouron, 1999). With the current phenomenon of widespread globalisation, as well as transnationalism, supranationalism and diaspora (Pries, 2005: 175 - 182), it is indeed impossible to conceive all members of one nation in a single state. Since this seems to be obvious both to scholars and political stakeholders, this "methodological nationalism" was rejected (Glick Schiller and Fouron, 1999). Today, the national community is understood as a network of individuals irrespective of their state of residence, the definition which can also be applied to the diaspora (Pries, 2005).

Contemporary technologies enable powerful states to exert their political and cultural influence on the rest of the world, which is reflected in the shaping and questioning of identities of non-migrants of various nationalities, as well as in modifying the national identities of those who do not live in their countries of origin. The Internet permits mobiles to sustain everyday relations with non-migrants in the homeland. In that way, there is no need to alter the feelings of core national belonging, either by their suppression or strengthening through nostalgia. New technologies enable migrants to retain bonds once established in other states and cultures upon their return, which affects the further shaping of divergent personal identities. This 
phenomenon of maintaining social ties beyond the borders of a single state is known as transnationalism (Pries, 2005).

Yet, wide access to communication technology produces ambivalent outcomes. It allows for an open future and a myriad of personal choices that alter the fixed core of sentiments linked to the idea of a nation. However, varied life trajectories in the current era of globalisation bring about the crisis of self, thereby underpinning national identity, which, contrary to expectations of hyperglobalists, has not been overcome, but instead, even more fortified. As Appadurai (1990) claims, the impact of globalisation on the national state and personal identity is much contested. Personal identity is explained by antagonistic views, especially the identity of migrants. In short, when it comes to the identity of migrants and diaspora, there are two main schools of thought:

1. Primordial, i.e. essentialist one - diaspora identity is seen as a purely national one in an ethnic or "demotic" sense, in line with Smith's classification based on ethnic origin, language, myths, and memories (Smith, 1998, 2009). According to Šolte (2009), transnational communities and diaspora are manifestations of how national identity has been conserved in the era of globalisation. The author observes them as consequences of deterritorialization where the progress in both technology and communications caused the generation of a new form of national identity irrespective of the borders of a (national) state (Šolte, 2009).

The main reason to emphasise the national element while tackling the identity of the diaspora lies with the very definition of that concept. According to Brubaker (2005), "diaspora" presupposes not only spatial dispersion but also concentration in a destination country and (re)orientation towards the homeland. The same author claims that the diaspora maintains a national identity as a reaction to or a rejection of being assimilated into destination society, but as he highlights, this sentiment has to endure through many generations (Brubaker, 2005: 5). The identity of members of the diaspora has not been shaped by passive citizenship in the origin country as is the case with national identity, but by their affection for the homeland while living as passive citizens in some other society. "The diasporic people survive in a new environment while caring for their distant homeland" (Bradatan, Popan and Melton, 2010: 177). Their emotional life is absorbed by the origin place and they feel like refugees in the country of destination. Besides, they are not interested in interactions with citizens in the country of destination but are instead obsessed with the moment of return. Authors 
advocating this standpoint reckon that immigrants create wholly isolated, homogenised ethnic groups denying any dissimilarities among their members (Basar, 2015: 20). They all feel that they only belong to one place: the country they came from. The problem with this view is that it neglects the issues of personal choice when it comes to belonging, thus widely overlooking the possibility of participating in (various) groups, although the latter presents the most important element of mobilising agency. Secondly, proposing total isolation of migrants in destination places and denying any influence of customs, values and cultural elements of local citizens seems rigid.

2. Opposed to the mentioned theoretical viewpoint is a group of authors in favour of constructionism, including Nina Glick Shiller, Steven Vertovec, and others (Bash, Glick Schiller and Szanton Blanc, 1994; Vertovec, 2001; Bauböck, 2010; Hall 1990). They claim that migrants are not necessarily focused either on the country of origin or to the destination but they might identify themselves with many places, communities, and societies. Thus, they can be "both here and there" while their belonging is essentially transnational. Glick Shiller considers that migrant identity is embedded in a network of relationships that are created simultaneously in both the destination and origin societies (Bash, Glick Schiller and Szanton Blanc, 1994). Similarly, Adamson reckons that the identity of the diaspora is a social construction made of transnational networks, experiences, and identifications, formed as a result of new advances in technology and communications (Adamson, 2008). These experiences refer to various cultural, political, economic and historical conditions, as well as institutions and practices, which without doubt contribute to migrants' identity formation (Christou, 2006: 19). Thus, when speaking of diaspora identity from this standpoint, it is the cultural change that is particularly emphasised, instead of its traditional content which is passed on from generation to generation in an unchanged form.

Extreme interpretations of the second viewpoint can be found with authors proposing hybrid diaspora identity (Chien-Hui Kuo, 2003; Korać, 2012; Bash, Glick Schiller and Blanc-Szanton, 1994; Vertovec, 2001). They deny the existence of the "hard core" of identity and insist on permanent change (Bruneau, 2010: 37). The cultural mixing begins once a migrant has settled in a destination country and invokes the processes of integration into a new society. This brings about the adjustment of one's homeland culture to the new one, its reconfiguration and the creation of a new, hybrid, mixed identity (Chambers, 1996: 50). In line with this standpoint, immigrants are con- 
nected with two places simultaneously, but they belong nowhere. That is why underscoring the very idea of a "space somewhere in between" seems important (Bhabha, 1990, 1994). This "in-between" space presupposes one core cultural narrative, producing a counter-narrative of a "third space". By that token, people occupying the "third space" are indeed seen as cultural brokers, such as elite intellectuals whose hybrid artistic products are the focus of academic interest (Korać, 2012; Kalra, Kalhon and Hutynuk, 2005).

A somewhat different type of constructionist standpoint is represented by authors who maintain the "hard core" of national identity, but see it as permanently remaking and reshaping owing to the cultural influence of destination places and societies. Bauböck considers national identity the main factor for mobilising diaspora (Bauböck, 2010), preserved for generations and upgraded by impacts of other cultures. As such, this notion of migrants' identity turns out to be an outcome of "roots and routes" (Gilroy, 1991). Members of the diaspora coming from the same (national) state have the same descent, irrespectively of their place of settlement. However, differences occur due to the effects of cultures and traditions they faced and exchanged during the course of mobility. Or, as Hall notices, "they bear upon them the traces of the particular cultures, traditions, languages, and histories by which they are shaped. The difference is that they are not and will never be unified in the old sense because they are irrevocably the product of several interlocking histories and cultures, belonging at one and the same time to several 'homes'"' (Hall 1990: 310).

When speaking of the identity of returnees, it should also be underlined that it implies more of a process and less of a closed and intact quality. The culture, value system and customs of the local societies where a person was upbrought are going to be further moulded by influences of the culture and customs into which s/he has been integrated during the migration trajectory. The very fact that migrants have experienced life in different states undermines the idea of homogenous group identity of returnees. This also applies to the diaspora. The myriads of identities of returnees could be classified in the following way:

1. Returnees - just like members of the diaspora - do not represent a homogenous group. Their identity has been built by combining "roots and routes", thus producing wholly dissimilar individual identities. Since current mobility assumes that more than two social systems will contribute to identity formation, the process of differentiation can be expected to become even more complex. 
2. In-between returnees and diaspora: although the very fact of residing in various states adds to modifications, the absence of nostalgia as a painful feeling of separateness from homeland profoundly distinguishes returnees from the diaspora. Still, these two groups have something in common other than roots. It is the experience of living in different states together with transnationalism in the sense of belonging to a wider, global community surpassing the borders of a (nation-) state (Vertovec, 1999) and not to be constrained by a national one. This implies that returnees do resume transnational practices, which involve simultaneous social, political and economic activities in their homeland, which has become their (new) destination, and in former destination places/states. They also continue participating in the transnational diaspora, professional, interest, and other groups.

3. In-between returnees and non-migrants - the identity of returnees has been shaped by influences of other societies and transnationalism. However, while direct exchange with foreign cultures is only related to migrants, transnational belonging is not their exclusive feature. With information technology and media, globalisation allows for the pursuit of transnational orientation regardless of "corporal" mobility (Levitt, 2003). Just like members of the diaspora, who do not need to travel to their homeland to experience a sense of belonging, non-mobiles are not to be denied transnationalism either (Smith and Guarnizo, 1998). Still, the fact remains that differences between returnees and non-migrants are often acknowledged through sentiments of "otherness" which are glued to the first group upon their return (cf. Takeyuki, 2001). This might be the result of diverging norms in countries of origin and destination or changes which the homeland underwent while migrants were away (De Bree, Davids and de Haas, 2010).

When speaking of the identity of both the diaspora and returnees, authors accentuate the dynamic side of the cultural aspect of national identity. However, some studies which tackled the functional role of national identity came to underline the political and territorial components as highly significant in the formation of personal identity (Baser, 2015; Šupule and Klave, 2018). In an interpretation of the role of the Turkish diaspora in the relations between Turks and Kurds in Turkey, Baser noticed an increase in the strength of national feelings following an escalation of conflicts in the home country. This was also reflected in the interactions occurring in destination countries such as Sweden and Germany (Baser, 2015: 169-206). The author carried out field research in these two countries among the second generation of migrants who have not expressed a willingness to return. So, 
his aim was not to study to what extent the political circumstances moulded their national sentiments and connections to the territory at the time of migration.

Another two scholars, Šupule and Klave (2018) undertook a study of the impact of these components on Latvian returnees. They emphasised feelings of belonging to the homeland as an important element of their motivation to return. These authors pointed to empirical evidence which indicated that feelings of belonging to a nation grew stronger at the times of major political events. For example, the respondents who were not living in Latvia during the referendum on accepting Russian as official language tried their best to engage in voting on the issue. In their understanding, this was not only a cultural matter, but also an issue of political relationships between the two states (Šupule and Klave, 2018). This is a strong argument demonstrating why it is important to take into account structural settings, which is already emphasised in the introduction by citing Cassarino.

Having in mind the relevance of a social context to the formation of personal identity and potential investment in the homeland, the next chapter lays down the dynamics of social change in Serbian society at the times when our respondents were leaving and returning to the country.

\section{SOCIAL CONTEXT}

According to Cassarino and other above-cited structuralists, the comprehension of the identity of highly educated returnees in terms of the preservation, strengthening, or, to the contrary, weakening of its national gradient, is very much linked to social contexts, both the actual one and the one they were moving out from and coming back to. Our oldest respondents left ex-SFRY, the state of relative economic well-being. State socialism spanned through years and decades, from the end of WWII up to the fall of the Berlin Wall in 1989. The latter event marked the implosion of socialist regimes all over Eastern Europe and their concomitant insertion into global capitalism. In the case of ex-SFRY, these processes were followed by armed conflicts in its territories.

In the years immediately after WWII, the communists, who emerged from the war as military winners, became political leaders of the federal state, although without the support of the vast majority of the population (Antonic, 2004: 24). Their legitimacy was based on their vision of industrialised, de- 
veloped and egalitarian society, which was fully in line with the prevailing ideals of egalitarianism in Serbia, as well as with ideas of a "demotic" and "protective" state (Antonić, 2004: 24-26). However, the first years of their government saw a mass wave of population emigration. It mostly involved soldiers, primarily from the territories where Serbs made up the autochthonous population (Krajina, Lika, Kordun, Banija, Herzegovina and Bosnia). Not only was this period characterised by the mobility of Serbs living out of Serbia but it is also well-known for the emigration of anti-communists, who declined to return even after the collapse of the communist/socialist regimes by the end of the 1980s (Filipović, 2012; Bobić and Vesković Anđelković, 2015).

Extensive nationalisation of the economy was performed during the postWWII period by the new elite through the expropriation of the means of production (except for those belonging to small farmers and craftsmen). This act endorsed high investment in industry, which concurrently caused the demise of entire social strata. Such a course put SFRY on the track of accelerated industrialisation. Nonetheless, as early as 1948, a major clash took part between the Yugoslav communists and the Soviet nomenklatura, marking a retreat from the Soviet model of socialist/communist regime.

In the case of SFRY, the confrontation contributed to the development of some specific features of the system and society. Still, very soon afterwards, SFRY faced a serious social and economic crisis, which was the result of a rebellion among farmers caused by a reduction in small farmland areas and the creation of agricultural cooperatives. Western states, most importantly the USA, initiated a programme of sending aid to Yugoslavia since they understood the huge geopolitical significance of president Tito's conflict with Stalin. Aiming to obtain continuous assistance from the West, Yugoslav authorities commenced the establishment of certain institutional and legitimacy patterns contrary to those of the Soviet regime. As a consequence, a distinctive model of Yugoslav workers' self-management socialism emerged, with elements of the market economy and a relatively liberal political regime partly open to the West (Lazić, 2011; Lazić and Pešić, 2012).

Increasing economic and political openness towards the West permitted both a relatively free exchange of ideas and goods and unrestricted mobility of people across national borders. ${ }^{2}$ Population emigration at the times was mostly motivated by economic needs (Antonijević, 2011; Filipović, 2012).

"Liberal" Yugoslav socialism gave space to strong social criticism in the fields of science and culture, which was followed by a low level of repression. 
However, already during that period, the share of unemployment was not low despite the relative material well-being. On the other hand, salaries were still below Western ones, although higher compared to other socialist countries.

Emigrants from Serbia were manual workers prompted by a need to enhance the material status of their households. They searched for jobs, most frequently settling in Germany, Austria, France, Belgium, Switzerland, and Sweden. That is why these states, together with overseas ones, are home to the vast majority of the Serbian diaspora today. After retirement or even earlier, when their savings would increase sufficiently to allow for a start of business or some other purpose, a substantial share of these migrants returned to Serbia. Due to the initial temporariness of their labour migration, they were commonly named "guest workers" (in German "der Gastarbeiter"). When it comes to the mobility of highly educated citizens from Serbia and former Yugoslavia, their number was minor, as a result of both their lower share in the general population and their confidence in local tertiary education and the social system.

The partial openness to Western Europe and North America, as well as the specificity of Yugoslav socialism, laid the ground for convictions that the country would easily and quickly transform itself into a market economy by the end of the 1980s. The so-called post-socialist transformation represents the process of "reintegration of Central and Eastern European countries into the capitalist (world) system" (Lazić, 2005: 122). It presupposes the acceptance of democratic values and institutions and revitalisation of market economy mechanisms.

Despite expectations, this process was quite prolonged and stalled in Serbia. The reasons should be sought in the particular model of structural transformation. More precisely, political and economic dominance was exercised by the groups originating directly from the previous generation of socialist leadership. Not only were those new/old elites unaware of the necessity of abandoning state socialism but they also strongly opposed any change whatsoever, which obstructed the transition to a capitalist social and political system. This process of blocked post-socialist transformation is defined as "a social movement set off by totalised social monopoly exerted by the previous class of socialist, collective-ownership leadership, which was replaced by the mutually enforcing economic and political domination of virtually identical social groups, whose aim was to postpone the ongoing instalment of the market economy and political competition" (Lazić, 2005: 
123). That was a period of extremely harsh economic and political conditions, marked by isolation and sanctions from the international community, as well as by armed conflicts on ex-Yugoslav territories.

Besides the forced population migration inside ex-Yugoslav republics, these times were also known for the mass emigration of a huge portion of highly educated people. They were prompted to leave Serbia due to forced military mobilisations, unwilling to take part in armed conflicts between ex-Yugoslav republics, and wishing to improve the quality of their lives. It was in the 1990s when the largest share of highly educated people left Serbia. ${ }^{3}$ At the same time, a significant number of those who emigrated in the 1970s and 1980s to improve their knowledge and expertise decided to come back and settle in Serbia despite the hardships. They were driven by various incentives, including the national ones.

The "de-blockage" of the post-socialist transformation started with the political opposition winning the local elections in 1996/1997 and ended in 2000 with the collapse of Milošević's regime (Lazić, 2005; Lazić and Pešić, 2012). Already by the end of 1995, after the Dayton agreement had been signed, bringing an end to the war in Bosnia and Herzegovina, sanctions were imposed against Serbia. This event marked the opening of Serbia to the West, which immediately facilitated economic emigration as a result of the prevailingly low standard in Serbia, which additionally deteriorated after the bombing by the NATO alliance in 1999 .

Expectations rose among ordinary people after Miloševićs overthrowing at the end of 2000. After the end of his decade-long domination, Serbia was quickly admitted back into the international community, with sanctions being fully removed. Financial aid was provided, sparking anticipation of a speedy economic recovery and stabilisation of the socio-political system. The new political elite in Serbia posed the priority goal of normalisation of capitalism. That meant: "stabilisation of the political system (introducing the principles of fair political competition), establishing legal order, ensuring institutional warrants for market principles in the economy and inclusion in the global system (economic, political, legal and cultural)" (Lazić, 2014: 25). However, very soon it became evident that Serbia was turning away from the "ideal type" of capitalism (the most developed countries or "core" ones being closest to it). That was best reflected in the Serbian

According to census data, in 2002, there were 34.380 people from Serbia with tertiary education who settled abroad, whereas their number was even higher in 2011 (41.185) (Predojević Despić, 2015: 159). 
economy. The state and the public sector retained a significant place in the economy, thus preserving not only a regulatory but also a direct economic role. ${ }^{4}$ In the reference literature, such a deviation from the classic model of capitalism in the long-term process of its inauguration is named "consolidation of the capitalist model" (Lazić, 2014; Lazić and Pešić, 2012).

Regardless of these aberrations from the core countries, Serbia was soon faced with a profoundly different attitude of the West, compared to that of the end of the previous century, especially in the first years after Milošević's fall. That was mirrored in the new approach of members of the European Union and the "strategy of accession", followed by an influx of donors' assistance to support the interior process of transformation in Serbia.

Additionally, higher foreign investments and international trade contributed to an enhancing living standard for a part of the domestic population (the so-called "winners" of the transformation - urban, better-educated professionals). "Macro-economic stabilisation, price liberalisation and economic recovery went hand in hand with the credit-driven, consumer-led economic growth, largely funded by foreign capital inflows (including foreign loans and workers' remittances, but also direct foreign investments)" (Uvalić, 2010, in: Lazić and Pešić, 2012: 55).

Still, "the ordinary man in Serbia remained discontented" (Antonić, 2004: 33) as a result of unmet expectations of a fast rise of the quality of life that would reach at least the level of Tito's times (especially in the 1970s). The economy was very slow and hard to recover, while living conditions remained poor, particularly when compared to Yugoslav state socialism or Western lifestyle. The situation was further exacerbated after 2008 with the onset of the world economic crisis that caused a drastic decrease in direct foreign aid and investments, an increase in unemployment and poverty in the country, as well as the accumulation of private and public debts (Lazić, 2014: 27).

The social setting in Serbia after 2000 influenced the migration of the highly educated population in a two-fold way. On the one hand, many members of the highly educated diaspora returned to the homeland, feeling encouraged to support auspicious, appealing changes. Their inclusion in the processes of social transformation was recognised and approved by their incorporation into a new elite class of politicians and experts (e.g. Zoran Đinđić, Božidar Đelić, Radovan Jelašić, Lazar Krstić, etc.).

$4 \quad$ The banking system was almost the only one entirely transferred to foreign owners. 
However, persevering problems in the administrative and legal system, undeveloped policies toward returnees, as well as the mentioned persistently difficult living conditions for the vast majority of the population, prompted many to leave the country again. Such a situation, including the everpresent challenges of the education system, has constituted "push" factors for the current emigration of the highly educated youth (Bobić, Vesković Anđelković and Kokotović Kanazir, 2016).

Last but not least, emigration from Serbia has been encouraged by immigration policies of developed countries, which embarked on a "struggle for talents", i.e. attracting young people through fellowships, projects, various programmes, etc. To sum up, although the dawn of the new millennium was marked by a high number of returns, primarily of those who were ready to participate in structural reforms occurring after 2000, the fact is that the highly educated Serbian diaspora, already numerous, has been continuously growing due to the constant emigration of young professionals (Mojić and Petrović, 2013; Bobić, Vesković Anđelković and Kokotović Kanazir, 2016).

\section{METHODOLOGY}

The fieldwork embraced several techniques and sources of data collection (primary and secondary). However, the present analysis of the identity of returnees is only founded on the qualitative study carried out using semi-structured interviews. The sample was created using quotas - the respondents were selected among highly educated returnees, aged 30-65, irrespective of their gender. The main principle of their selection was set out according to the presented delineation of phases of social transformation in Serbia. Such a choice was also motivated by the wish to undertake comparative research on the influence of different structural factors. Therefore, the informants fitted into three different groups: the first one, made up of those who returned already under Milošević's regime (1989-2000), the second one, encompassing those who came back between the political change in 2000 and the onset of the world economic crisis in 2008, and the third one, covering migrants who have returned since 2008 to the present.

The first group consisted of 18 informants; 10 men and 8 women. The second encompassed 14 returnees -8 men and 6 women, while the third one included 15 highly educated returnees; 9 women and 6 men. The ter- 
ritorial distribution was not set out in advance, but it turned out that most interviewees came from Belgrade. A vast majority, as many as 39 , left the country for the sake of further education, five to reunite with family, and as few as three left for work-related reasons. Most of them, 39, completed undergraduate studies in Serbia, whereas five obtained a Ph.D. in Serbia. All of them left the country to enrol in further education, take part in a research project, or teach as a guest lecturer at some of the world universities. The largest number, 15, headed to the USA (most often the respondents who left before 2000), eight went to Canada (again, prevailingly those who left before Milošević's fall), whereas one spent part of his life in China, one in Australia, one in Russia, and the rest, 22, in some of the countries of the European Union, most often France (8) and Germany (6).

The main objective of the entire research was to explore the possibilities and readiness of returnees to actively participate in the social progress of Serbia, especially as brokers between the homeland and academic diaspora, efficiently and effectively directing their disposable resources amassed while staying abroad. One of the explicable objectives was to assess the sentiments related to national identity, implying that such sentiments possess a mobilising power when it comes to investments (Nielsen and Riddle, 2007; Filipović, 2012). This led to the idea that one part of the collected data would serve the purpose of analysing the respondents' identity formation.

While designing the protocol of the interview, the recreation of identity was conceptualised as an ongoing process. The initial hypothesis based on the above conceptual discussion reads that the identity of migrants/ returnees is a fusion of national identity and influences of societies they have been living in. Accordingly, the respondents shared their answers to several questions.

Firstly, it was important to comprehend national identity, which was operationalised in the interview by posing the following question: "What does national identity mean to you?" It aimed to explore whether and to what extent the cultural, political and territorial components were recognised by interlocutors as important elements of national identity. The following question was asked to understand their view on the effect of migration on identity formation and its alteration: "Having lived in another society with different rules, values, culture... what has changed, if anything, in your personal identity?". It was valuable to assess the impact of different cus- 
toms, behaviours, cultural norms and languages on identity formation and change over time.

Finally, the intensity of national identity in various phases of the migration process was examined by asking the following three questions: "Did you find this sentiment stronger while living out of Serbia or upon return?", "What were your feelings when you finally came back?", "Has anything changed in your understanding of personal and group identity?". It is important to stress that the focus was placed on respondents' personal views on the effect of various cultures and living in different states on self-identity. Thus, this was not a comparative study of different groups - the diaspora, non-migrants, and returnees. Instead, the results only concern the returnees, since, at the time of preparing this paper, the research of another two groups was not completed yet.

\section{RESULTS AND DISCUSSION}

The notion of identity used in the analysis of the collected data is related to personal feelings and performance (Brubaker, 2004). Individual consciousness is reflected in the understanding of one's own identity on one hand, and sentiments of belonging on the other. If a sense of belonging does not exist, there is no identity but identification instead (Golubović, 1999). The present paper examined group or collective identity taking into account the fact of preservation and even strengthening of national identity in the current age of globalisation. It was important to capture a potential change in the meanings of national identity under the influence of present-day society.

First and foremost, it is interesting to underline that almost half of the interviewees (19) did not respond to the question of how they perceived national identity. The replies revolved around a statement on their belonging to groups such as family, close friends, and professional organisations or even migrant groups. Still, one should bear in mind that even though some respondents did not wish to comment on national identity, or denied any national component in their personal feelings of belonging, later in the interview they did speak about the emotional connection to Serbia in terms of relatedness to its people, way of life and institutions. This can be understood as a consequence of individualisation, which is one of the most salient features of the contemporary world, stemming from the plurality of choices and chances, and social networking. A female respondent said: 
I am definitely not a nationalist, because I have always considered myself a citizen of the world. But there are friends and family who relate me to Serbia mostly. (R. J., female, 35, lived in France, 2006-2012) ${ }^{5}$

Here, the territorial component is evident in the discourse of the interlocutor. Other than that, one may also observe the confusion of the concept of national identity with nationalism as an ideology. The latter is treated as a disadvantage nowadays since it is seen as the core of all conflicts in international relationships. Still, this national ingredient was noticed in almost all respondents, even though some of them did not admit it explicitly. Similarly, some other interviewees talked about national identity with disgust, although it could be traced in their overall discourse:

National identity? Well, that nationalist ideology almost killed us! How luckier we would have been had it never existed. (R. M., male, 58, Canada, 1994-2005)

However, a little later, the same interlocutor demonstrated outstanding attachment to Serbia in both a territorial and cultural sense. He continued:

You do not become Canadian merely by living in Canada. I cannot be happy there if I have to do the same things they do. Then, the climate does not fit me either... So, I walk around Vancouver and think about Babušnica [a small town at the southeast of Serbia] - April, violets, birds, sitting with my childhood friend and drinking brandy. And Djurdjevdan is coming soon [slava ${ }^{6}$ ]. That was a big holiday when I was little. These are the things I was thinking about. (R. M., male, 58, Canada, 1994-2005).

Unlike the respondents who refused to even reflect on national identity ${ }^{7}$ at the beginning of the interview, others offered very precise statements clearly showing their national loyalty. Here stands out the narrative of a female informant who was not even born in Serbia, but whose discourse is fully in line with the so-called "demotic" model of national identity, highlighting the cultural component:

What makes me Serbian is the language, religion, tradition, and that is that ... I have a half-sister who is not Serbian, but when she comes here, she has to

5 When citing parts of the interviews with respondents, only their initials are noted together with the country where they lived and the respective length of their stay.

6 Slava is a Serbian Orthodox Christian tradition of the ritual glorification of one's family's patron saint. The family celebrates the Slava annually on the saint's feast day (authors' note, see: https://en.wikipedia.org/wiki/Slava, (23th June, 2018).

7 This might be the result of the disintegration of ex-Yugoslavia and the specific, concomitant problems reflected in the interior and foreign policies of the Republic of Serbia related to its national identity - e.g. Kosovo as a clear example. 
eat pasulj [famous national dish - beans]. Slava has to be celebrated. (S. A., female, 40, born in France, returned to the homeland in 2002)

The following interviewee expresses the transnational identity of migrants, constituting a sum of roots and routes, i.e. national identity modified through relationships with people in other societies, whereas national identity mainly seals individual identity:

You see... I observe a human being from the aspect of identity and technological parts. The first is the one which changes very slowly and cannot be induced. For me, there are accumulated things which do not alter, practically, it is hard to assume that some people change at all, maybe only in some fragments, but yes, it is something... I would say, if I had gone to America as a Serb and received a Ph.D. there and become someone else, then it would not be me anymore, not the person I had struggled for, it would be some other person, not myself. (J. F., male, 55, USA, 1988-1994)

Still, unlike the majority of respondents, who more or less explicitly expressed a connection to the homeland in general or a local community in particular, a minority of them declared that origin did not have any effect on their identity. They are classified as those who built hybrid identities in a somewhat extreme form. Here is an example:

Regardless of your religion or nation, you [authors' emphasis] are the site where your character has been moulded. You might be named Nikola Petrović, but if you were raised in Canada, you are Canadian. And vice versa. Society and the setting produce a great impact on you. That stems from your surroundings. I am proud of what I have become, I do not adhere to any extremes... I am always ready to defend my position with arguments, what I am and who I am. (M. M., male, 30, USA, 2012-2016)

Likewise, a female respondent says:

I grew up in some parallel universe and that, national identity, I identify with a group of my friends, because I spent a lot of time elaborating my inquisitiveness. Although I come from a small place, without any industry, any hope, my national identity has often gained some other features and has been directed towards those people who shared similar interests. Some sort of polarisation - I see it also in social media [she spoke about Facebook], people often think as if, that national identity is very fluid. (M. M., female, 31, Germany, 2010-2012)

The interpretation of the results indicates that younger respondents assign less importance to national identity compared to the older ones. As time passes by, however, the feeling of belonging seems to intensify: 
But what I can give as a conclusion after some years of thinking, and since I am getting "older", the sentiment of belonging to a nation and national identity have been reinforced, have become something sound, affirmative and not aggressive. For a long time, I thought that it was the consequence of living abroad, but now I think I was not right. (A. M., male, 31, Germany, 2012-2016)

Pushing aside and even neglecting national identity may be understood as a result of information technology and wide access to cheap transportation, which diminish the sense of nostalgia as one of the main components of group (national) identity. Secondly, one should take into consideration the relative political stabilisation of Serbia at the times when younger cohorts were leaving and returning. It seems that they missed a strong basis for the burgeoning of national sentiments, as had been the case with older cohorts, who had moved out in the 1990s.

It was at those times of warfare here, then, that the feeling was the strongest. (M. M., male, 58, France, 1989-1994)

In the times of turbulence and crisis in Serbia, the political element of national identity gained its importance, with feelings of "otherness" becoming more emphasised, not infrequently followed by anxiety and paranoia:

While living abroad, I was in a very unpleasant situation because it was at the time when Kosovo... [unilaterally claimed autonomy and independence from Serbia]... when those decisions were being made in the European Parliament. I had rows with people, especially Swedes whom I knew, who thought that we were all war criminals, and you had to defend yourself, willingly or unwillingly. Americans were not nice either, all of those who grew up watching CNN. (M. M., female, 40, Italy and Belgium, 2002-2008)

When there were wars here and when we were presented on CNN as animals, I felt as if I was facing discrimination. I hardly made up my mind to take an exam. And then I came and he [the professor] saw that it was written there that I was from Yugoslavia and he asked me if I was maybe a Serb or Croat. Then I understood that they only minded their own business. (V. B., male, 57, Australia).

However, regardless of the situation in Serbia and the age of our respondents, they still felt different when comparing themselves to people at the destination:

You start doing things in a different way. You need to enter the social circle. People are much more reserved there. It was not easy. A long time passes before someone asks you to come and have a coffee at his/her home,... On the other 
side, their bureaucracy is completely different, and indeed you need some time to come to terms. When you are alone in some foreign country, it is also a kind of a challenge. There are also obvious cultural differences because they are more restrained. My sincerity was incorrectly understood there, especially by young men. In the beginning, everyone called me using "You" [in French]. Of course, as time went by, Frenchmen became somewhat warmer, but it was not the case at the beginning of my studies. I think that it is some distance which is not favourable among students. But still, I kept something of my Southern mentality. (R. J., female, 34, France, 2006-2012)

Well, you are actually always a foreigner, but you have to accommodate and to feel pleasant. Language is also a big barrier. Before I started speaking Italian, I did not have friends. I had one girlfriend who worked for my husband and was 80 years old, she was the only one I got around to at the beginning. I felt that I did not belong to that society for a long time. That bonding was not fantastic, a lot of time had to pass. It was by far easier in Italy compared to Belgium, because Belgians are much colder, especially the Flemish. (M. M., female, 40, Italy and Belgium, 2002-2008)

Regardless of the sense of exclusion, most respondents were not interested in socialising with the Serbian diaspora. This is especially the case with the youth:

Well no, not at all, I had no wish to chase our people there. I could have done that here, in Belgrade. That idea was worthless for me... I had actually left Serbia because I wished for something new, both the environment and people. (A. M., 30, England and Italy, 2014-2016)

However, one respondent, who returned to Serbia during the peak of the crisis in the 1990s, had a completely different experience:

It was important to me that there were our people. You know when you yearn for everything and then you happen to hear Serbian. And you cook sarma and pasulj [famous Serbian dishes]. We did all that. These "others" [citizens of different nationalities] were all around and yes, I did mingle with them, too. But it is not the same. My heart is full when I know that we are all the same. (A. V., male, 59, USA, 1984-1998)

When looking from a generational perspective, we can recognise another regularity -the integration of the national component into personal identity constituted an incentive to return, primarily among older respondents, who had left Serbia before the collapse of the socialist state of Yugoslavia: 
Personal identity is one of the reasons why I came back, and I wished to find out where my roots were. (D. N., female, 44, Germany, 1987-2007)

Yet, younger interviewees, who travelled abroad, supported by either some programme, such as Erasmus or some foreign organisation, very often had to return after their fellowships expired. They all emphasise subsistence as a key motif:

I have returned after completing my Master's degree in France and I was lucky that a position was opened here at the faculty and I got the job ... You know, you receive resources for your work there and intellectual support from the leading people in your field, but it is not easy to find a job. The competition is tough. And they have the practice to admit their own people first, and others afterwards, provided there are still some vacancies. (R. J., female, 34, France, 2006-2012)

Well no, I had no intention to stay there. I did not have a job. Here, I arrived and gained a certain position. (A. M., male, 30, England and Italy, 2014-2016)

None of the respondents underscored "otherness" in terms of full differentiation from non-migrants when it comes to national identity. At the same time, they still acknowledged that living abroad had changed their personalities. Whether they spent time with members of the Serbian diaspora or not, they claimed that they shared common sentiments related to the nation.

With me personally, a lot of things have changed. Well, you know, everything is so individual, few people return, the majority stays, I cannot speak for the latter. But regarding those who came back, it is all up to an individual and depends on people; perhaps you become more mature as a person, you find yourself somewhere where you don't feel familiar... I underwent a crisis, but you are not the only one to go through that... and so you come to understand that all of us are made up of the same stuff. (J. M., female, 52, Switzerland, 2000-2006)

Although all our informants perceive identity in a somewhat different way compared to Serbians who have never moved out, none of the migrants/ returnees was keen to deny the contribution of non-mobiles to the preservation of national identity.

Someone had to stay and look after Serbian universities while we were there. (J. F., male, 55, USA, 1988-1994) 


\section{CONCLUDING REMARKS}

The research confirms the social constructivist viewpoint according to which the identity of returnees has been moulded through the active interaction between the national culture and customs and those of the destination countries. Nevertheless, the national element is not equally emphasised - it is least recognised among the narratives of younger respondents. This could be interpreted as an impact of globalisation, widespread electronic media and the culture ascribing a negative connotation to the individual nation. Yet, this explorative research has demonstrated that even the young informants quote national elements when describing their personal sentiments.

It seems that the most important is the territorial component, vastly reflected in the feelings of belonging to a local community and usually restricted to families and friends. Quite a small number of respondents did not refer to any tradition, language, or custom adopted in the family of origin, which indicates that the cultural component makes the largest contribution to the preservation of national identity. The dominance of the cultural element varied depending on both the actual place of living and the social, economic and political conditions at the homeland. This was especially pronounced while respondents were living abroad and it grew stronger in times of crisis. This suggests a strong influence of the political factor on the perseverance of national identity.

Additionally, it has been demonstrated that the more socially included the respondents were at the destination, the less significant their national identity was. As we could see from the interviews, national identity is at the core of the sense of personal belonging for the respondents who left the country in the 1990s, when there were armed conflicts in ex-Yugoslavia and when living in Serbia was extremely harsh due to the economic breakdown and sanctions imposed by powerful Western states. Their discourse reflected a rebellion sparked by the media campaigns against Serbs, which in turn reinforced the national element.

The respondents' age, as well as the time when they had left the country, were also significant when discussing similarity with the Serbian diaspora. The informants who had left and lived abroad earlier were mostly interested in getting along with expatriates, whereas the younger respondents, having left recently through exchange programmes and short-term fellowships, steered clear of Serbs at the destination. Nevertheless, this fact does 
not deny their sentiments of belonging but stresses the need to expand their social capital beyond the national frontiers.

Last but not least, it seems important to stress that the respondents very often underlined that national identity had been the main reason behind their return. Still, many were "pushed" back due to the expiration of fellowships and the inability to find a job. However, this research did not show that the returnees who do not emphasise components of national identity differ strongly from non-migrants. All our informants pointed out that the experiences of mobility had vastly changed them and provided them with a lot of benefits, but they also expressed an appreciation for non-migrants who stayed and preserved the Serbian culture and institutions.

\section{REFERENCES}

Adamson, F. B. (2008). Constructing the diaspora: Diaspora identity politics and transnational social movements, 49th meeting of the International Studies Association, San Francisco, CA, 26-29 March, 2008.

Anderson, B. (1999). Nation: Imagined Community. New York: Verso.

Antonić, S. (2004). Društvena osnova i sadašnji pokušaj modernizacije, in: Milić, A. (ed.). Društvena transformacija i strategija društvenih grupa: svakodnevica Srbije na početku trećeg milenijuma. Beograd: ISI FF, 19-37.

Antonijević, D. (2011). Gastarbajter kao liminalno biće: konceptualizacija kulturnog identiteta, Etnoantropološki problemi, 6 (4): 1013-1033.

Appadurai, A. (1990). Disjunctrure and Difference in the Global Cultural Economy, in: M. Featherstone (ed.). Global Culture. Nationalism, Globalization and Modernity. London: Sage Publications, 295-310.

Baser, B. (2015). Diaspora and Homeland Conflicts. A Comparative Perspectives. Burlington: Ashgate.

Bash, L., Glick Schiller, N. and Szanton Blanc, C. (1994). Nations Unbound: Transnational Project, Postcolonial Predicaments and Deterritorialized Nation-States. Amsterdam: B.V. Published.

Bauböck, R. (2010). Cold constellations and hot identities: Political theory questions about transnationalism and diaspora, in: R. Bauböck and T. Faist (eds). Diaspora and Transnationaism: Concepts, Theories and Methods. Amsterdam: Amsterdam University Press, 295-321.

Bauman, Z. (1994). Alone Again - Ethics After Certainty. London: Demos.

Bhabha, H. (1990). Nation and Narration. London: Routledge.

Bhabha, H. (1994). The Location of Culture. London: Routledge.

Bisley, N. (2007). Rethinking Globalization. Basingstoke - New York: Palgrave Macmillan.

Bobić, M., Vesković Anđelković, M. and Kokotović Kanazir, V. (2016). Study on External and Internal Migration of Serbia's Citzens with particular focus on Youth. Beograd: IOM.

Bobić, M. and Vesković Anđelković, M. (2015). Partnerstvo sa dijasporom kao strategija smanjenja siromaštva na lokalnom nivou, Sociološki godišnjak, 10: 89-109. 
Bradatan, C., Popan, A. and Melton, R. (2010). Transnationality as a fluid social identity, Social Identities, 16 (2): 169-178.

Brubaker, R. (2004). Ethnicity without Groups. Cambridge - London: Harvard University Press.

Bruneau, M. (2010). Diasporas, Transnational Spaces and Communities, in: R. Bauböck and T. Faist (eds). Diaspora and Transnationalism: Concepts, Theories and Methods. Amsterdam: Amsterdam University Press, 35-49.

Cassarino, J.-P. (2004). Theorising Return Migration: The Conceptual Approach to Return Migrants Revisited, International Journal on Multicultural Societies, 6 (2): 253279.

Chambers, I. (1996). Signs of Silence, Lines and Listening, in: I. Chambers and L. Curti (eds). The Post-colonial Question. London - New York: Routledge, 47-62.

Chien-Hui Kuo, K. (2003). A euphoria of transcultural hibridity: is multiculturalism possible?, Postcolonial Studies, 6 (2): 223-235, doi:https://doi.org/10.1080/13688790308104

Christou, A. (2006). Narratives of Place, Culture and Identity. Second-Generation GreekAmericans Return Home. Amsterdam: Amsterdam University Press.

De Bree, J., Davids, T. and de Haas, H. (2010). Post-return experiences and transnational belonging of return migrants: a Dutch-Moroccan case study, Global Networks, 10 (4): 489-509.

Đurić, J. (2009). O održivosti identiteta, Filozofija i društvo, 20 (3): 199-222.

Filipović, J. (2012). Management of a Diaspora Virtual University as a Complex Organization, Serbian Diaspora Virtual University: An Emerging Leadership of a Nation. Saarbrücken: Lambert Academic Publishing.

Gilroy, P. (1991). It Ain't Where You're From, It's Where You're At ...: The Dialectics of Diasporic Identification, Third Text, 5 (13): 3-16, doi: https://doi. org/10.1080/09528829108576284

Glick Schiller, N., Basch, L. and Blanc-Szanton, C. (1992). Transnationalism: A New Analitic Framework for Understanding Migration, Annals of the New York Academy for Sciences, 645 (1): 1-24, doi: https://doi.org/10.1111/j.1749-6632.1992.tb33484.x

Glick Schiller, N. and Fouron, G. E. (1999). Terrains of blood and nation: Haitian transnational social field, Ethnic and Racial Studies, 22 (2): 340-366, doi: https://doi. org/10.1080/014198799329512

Golubović, Z. (2009). Ja i drugi. Beograd: Republika.

Hall, S. (1990). Cultural Identity and Diaspora, in: J. Rutherford (ed.). Identity: Community, Culture, Difference. London: Lawrence \& Wishart, 222-238.

Held, D. and McGrew, A. (1999). Global Transformations: Politics, Economics and Culture. Cambridge: Polity Press.

Kalra, V., Kalhon, R. K. and Hutynuk, J. (2005). Diaspora \& Hybridity. London - New Delhi: Sage Publications.

Kelner, D. (2004). Medijska kultura. Beograd: Clio.

Korać, M. (2012). U potrazi za domom. Beograd: Zavod za udžbenike i nastavna sredstva.

Lazić, M. (2005). Promene i otpori. Beograd: Filip Višnjić.

Lazić, M. (2011). Čekajući kapitalizam. Beograd: Službeni glasnik.

Lazić, M. (2014). Uvod, in: M. Lazić (ed.). Ekonomska elita u Srbiji u period konsolidacije kapitalističkog poretka. Beograd: ISI FF - Čigoja štampa, 9-36. 
Lazić, M. and Pešić, J. (2012). Making and Unmaking. State Centered Capitalism in Serbia. Beograd: Institute for Sociological Research, Faculty of Philosophy - Čigoja štampa.

Levitt, P. (2003). Keeping feet in both worlds: transnational practices and immigrant incorporation in the United States, in: C. Joppke and E. Morawska (eds). Toward Assimilation and Citizenship: Immigrants in Liberal Nation-states. Basingstoke: Palgrave Macmillan, 177-194.

Mojić, D. and Petrović, I. (2013). Mladi i legitimnost društvenog poretka u Srbiji: razmišljanja i delanja u pravcu emigracija, Sociologija, 55 (2): 229-244, doi: https://doi. org/10.2298/SOC1302229M

Nielsen, T. M. and Riddle, L. (2007). Why Diaspora Invest in the Homeland: A Conceptual Model of Motivation, SSRN, 1-36, doi: http://dx.doi.org/10.2139/ssrn.987725

Pavković, A. and Radan, P. (2008). Stvaranje novih država. Beograd: Službeni glasnik.

Predojević Despić, J. (2015). Migracije visokoobrazovanih lica iz Srbije od 1991. u Kanadu i Sjedinjene Američke Države (PhD thesis). Beograd: Ekonomski fakultet.

Pries, L. (2005). Configurations of geographic and societal spaces: a sociological proposal between "methodological nationalism" and the "spaces of flows", Global Networks, 5 (2): 167-190, doi: https://doi.org/10.1111/j.1471-0374.2005.00113.x

Smith, A. D. (1998). Nacionalni identitet. Beograd: Biblioteka XX vek.

Smith, A. D. (2009). Etno-symbolism and Nationalism: A cultural approach. New York: Routledge.

Smith, M. P. and Guarnizo, L. E. (1998). The Location of Transnationalism, in: M. P. Smith and L. E. Guarnizio (eds). Transnationalism from Below. New Brunswick London: Transaction Publishers, 1-32.

Šolte, J. A. (2009). Globalizacija: kritički uvod. Podgorica: CID.

Šupule, I. and Klave, E. (2018). Belonging and Returning home: Deconstructions of Latvian Returnees' National Identity, Humanities and Social Sciences: Latvia, 26 (1): 4-24, doi: https://doi.org/10.22364/hssl.26.1.1

Takeyuki (Gaku), T. (2001). From Ethnic Affinity to Alienation in the Global Ecumene: The Encounter between the Japanese and Japanese-Brazilian Return Migrants, Diaspora: A Journal of Transnational Studies, 10 (1): 53-91, doi: https://doi.org/10.1353/ dsp.2011.0047

Vertovec, S. (2001). Transnational Social Formations: Towards Conceptual CrossFertilization, Transnational Migration: Comparative Perspectives, Princeton, June 30-July 1, 2001, https://www.researchgate.net/publication/240638360_Transnational_social_ formations_Towards_conceptual_cross-fertilization_WPTC-01-16 (20 February 2016).

Welman, B. (2001). Physical Place and Syber Place: The Rice of Personalized Networking, International Journal of Urban and Regional Research, 25 (2): 227-252, doi: https://doi. org/10.1111/1468-2427.00309

Žižek, S. (2001). Multikulturalizam, globalizacija i novi svetski poredak, Nova srpska politička misao, 8 (1-4): 75-96. 


\title{
Identitet visokoobrazovanih povratnika u Srbiji
}

\author{
Milica Vesković Anđelković, Mirjana Bobić
}

\begin{abstract}
SAŽETAK
U radu se predstavljaju rezultati istraživanja na temelju intervjua s pedeset visokoobrazovanih povratnika u Srbiji, provedenog 2017. Osnovni cilj bio je da se analiziraju i razumiju osobni i grupni identiteti građana Srbije s migracijskim iskustvom. Autorice su primijenile dvije konceptualne paradigme: prvu, primordijalnu - koja pretpostavlja da migranti u potpunosti čuvaju nacionalni identitet, bez obzira na to što su izloženi utjecaju različitih kultura, običaja i vrijednosti u mjestima odredišta; drugu - socijalnokonstruktivističku, koja je dalje podijeljena na dvije linije razmišljanja. Prva pretpostavlja da migranti zadržavaju nacionalni identitet kao »tvrdu jezgru «, koja je, doduše, u stalnom procesu mijenjanja i preoblikovanja uslijed uključivanja migranata u transnacionalne veze, a druga implicira da migranti grade hibridne identitete, koji su u permanentnom kretanju jer ispitanici nisu ukorijenjeni ni $\mathrm{u}$ jednoj posebnoj kulturi. Interpretacija rezultata pokazuje da većina visokoobrazovanih migranata povratnika izgrađuje hibridne identitete. To znači da društvo i kultura u mjestima odredišta imaju značajan učinak, no ipak se čuvaju nacionalni korijeni. To se ogleda u njihovu snažnom osjećaju nacionalne pripadnosti. Tumačenje ovog nalaza povezano je s dva glavna razloga. Nacionalni identitet ne može ostati nepromijenjen procesom uključivanja ispitanika u obrazovni sustav $\mathrm{u}$ inozemstvu i građenja veza s visokoobrazovanim slojevima širom svijeta. Usto, sama činjenica konzerviranja nacionalnog identiteta svakako je utjecala na njihov povratak i uključivanje u razvoj matične nacionalne države, bez obzira na veliko zaostajanje Srbije u socijalnom i ekonomskom razvoju u odnosu na njihove države emigracije. Rezultati su također otkrili da visokoobrazovani povratnici ne uviđaju naročite razlike $u$ nacionalnim osjećajima pripadnosti $u$ odnosu na sunarodnjake koji nemaju migracijsko iskustvo, dok iste te razlike primjećuju u odnosu na pripadnike srpske dijaspore.
\end{abstract}

KLJUČNE RIJEČI: identitet, dijaspora, transnacionalizam, visokoobrazovani povratnici, Srbija 
